\title{
Biological aspects of Blissus pulchellus Montadon (Hemiptera: Blissidae) regarding the resistance of forage poaceae
}

\author{
Jaime Edson Simon ${ }^{1 *} \oplus$, Edgley Soares da Silva ${ }^{1} \oplus$, Roberto Dantas de Medeiros ${ }^{2}$, Antonio Cesar Silva Lima ${ }^{1}{ }^{\oplus}$,

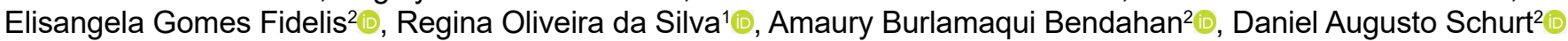 \\ 1 Universidade Federal de Roraima, Boa Vista, RR, Brasil. E-mail: jajasimon@yahoo.com.br; edgleyrr@gmail.com; cesar.lima@ufrr.br; reginazootecnista@hotmail.com \\ 22Embrapa Roraima, Boa Vista, RR, Brasil. E-mail: roberto.medeiros@embrapa.br; elisangela.fidelis@embrapa.br; amaury.bendahan@embrapa.br; daniel.schurt@embrapa.br
}

ABSTRACT: The objective of this study is to evaluate the biological development of the chinch bug, Blissus pulchellus regarding the resistance of the eight forage poaceae. For that, chinch bugs collected from a pasture area, in Boa Vista, Roraima, Brazil, were taken to the Embrapa Roraima Entomology Laboratory for evaluation. The mass breeding of $B$. pulchellus was carried out in B.O.D., on Urochloa ruziziensis and the biological development evaluation was carried out on eight forage poaceae: Urochloa ruziziensis, U. humidicola, U. brizantha cv. Marandú, U. brizantha cv. Piatã, U. brizantha cv. Paiaguás, Panicum maximum cv. Mombaça, P. maximum cv. Zuri and Andropogon gayanus. The results obtained allowed us to conclude that: a) $A$. gayanus, $P$. maximum cv. Zuri and $U$. humidicola, negatively affect the biology of $B$. pulchellus; $b) A$. gayanus, $P$. maximum cv. Zuri present high and moderate resistance $U$. humidicola, of the type antibiosis to $B$. pulchellus and c) Urochloa ruziziensis, $U$. brizantha cv. Paiaguás and $U$. brizantha cv. Piatã, have high grade and $P$. maximum cv. Mombasa and U. brizantha cv. Marandú, less susceptibility to $B$. pulchellus.

Key words: antibiosis; host plant resistance; insect-pest; pasture pests; Poaceae

\section{Aspectos biológicos de Blissus pulchellus Montadon (Hemiptera: Blissidae) quanto à resistência de poáceas forrageiras}

RESUMO: Objetivou-se com o presente estudo foi avaliar o desenvolvimento biológico do percevejo-das-gramíneas, Blissus pulchellus quanto à resistência de oito poáceas forrageiras. Para tanto, percevejos foram coletados de uma área de pastagem, em Boa Vista, Roraima, Brasil, e conduzidos ao Laboratório de Entomologia da Embrapa Roraima. A criação de B. pulchellus foi realizada em B.O.D., sobre Urochloa ruziziensis e a avaliação do desenvolvimento biológico foi realizada em oito poáceas forrageiras: Urochloa ruziziensis, U. humidicola, U. brizantha cv. Marandú, U. brizantha cv. Piatã, U. brizantha cv. Paiaguás, Panicum maximum cv. Mombaça, P. maximum cv. Zuri e Andropogon gayanus. Os resultados obtidos perrmitiram concluir que: a) A. gayanus, $P$. maximum cv. Zuri e $U$. humidicola, afetam negativamente a biologia de $B$. pulchellus; b) $A$. gayanus, P. maximum cv. Zuri apresentam alta e $U$. humidicola moderada resistência, do tipo antibiose a B. pulchellus; e, c) Urochloa ruziziensis, $U$. brizantha cv. Paiaguás e $U$. brizantha cv. Piatã, apresentam alto grau e $P$. maximum cv. Mombaça e $U$. brizantha cv. Marandú, menor grau de suscetibilidade a B. pulchellus.

Palavras-chave: antibiose; resistência de plantas a insetos; inseto-praga; pragas de pastagens; Poaceae

\footnotetext{
* Jaime Edson Simon - E-mail: jajasimon@yahoo.com.br (Corresponding author)

Associate Editor: Elton Lúcio de Araújo
} 


\section{Introduction}

Bed bugs of the genus Blissus, also known as the Grasshopper, have a wide geographic distribution and are found in many different regions of the world, with the exception of Australia (Spike et al., 1993). They are specialized on poaceae and many of them are considered important pests on crops of corn (Zea mays), wheat (Triticum spp. L.), sorghum (Sorghum bicolor), forage species and turfgrass (Ramm et al., 2015).

In Brazil, so far, only four species of grasshoppers, Blissus busq, Blissus antillus, Blissus leucopterus, and Blissus pulchellus (Hemiptera: Blissidae) have been recorded as occurring in the country (Pereira \& Silva, 1988; Valério et al., 2015; Simon et. al., 2016). Infestations are distributed mainly in the Southeast and Midwest regions, where the insects are almost exclusively associated with tanner grass (Urochloa arrecta), ragweed ( $U$. mutica), and ragweed (U. arrecta $\times U$. mutica) (Ohashi et al., 1980; Valério et al., 2015).

In the North region, in the State of Roraima, in 1995, the species $B$. leucopterus was found infesting the rice crop (Oryza sativa) (Moreira, 1996) and in 2016, B. pulchellus was observed causing severe damage in Urochloa brizantha and Panicum maximum cv. Mombaça (Simon et. al., 2016), this being the first report of B. pulchellus in Brazil (Silva, 2018).

The damage caused by bed bugs in forage plants results from the feeding of the nymphs and adults, which insert their stylus-like mouthparts into the conducting vessels, sucking up the liquid portions, and injecting harmful toxins. By destroying the vessels, they hinder the transport of water and nutrients causing water imbalance and, even in periods with high rainfall, the plants wither, bringing serious damage to the maintenance of pastures (Rangasamy et al., 2009; Rangasamy et al., 2015).

To circumvent economic losses, studies on forage species resistance to insect pests have been widely practiced, mainly due to the environmental approach that guides the integrated management, valuing the biological, genetic and cultural control (Cao et al., 2015). According to Boiça Júnior et al. (2016) forage insect resistance is mainly associated with genetic quality mechanisms, which influence the degree of injury caused during feeding. When chemical mechanisms, present in the plant, negatively affect the biology of the insect, without interfering in its feeding behavior, one can claim the existence of antibiosis type resistance (Liu et al., 2017; Wu et al., 2017).

The selection of plants/varieties resistant to insects by antixenosis and/or antibiosis, can be interpreted by means of insect responses to them, leading in turn to difficulties in isolating the causes of resistance (Baldin et al., 2019). However, studies have been developed seeking the identification and recommendation of materials resistant to the wireworm bug.

Milla-Lewis et al. (2017) evaluating the biological development of grasshopper bugs on four cultivars of Stenotaphrum secundatum (Bitter Blue, Floratam, FX-10, and Seville) and on three other poaceae (Paspalum notatum,
Cynodon dactylon, and Emochloa ophiuroides), observed lower oviposition and insect survival rates on the FX-10 cultivar, classifying it as resistant. The same authors also considered a poacea resistant when the mortality rates of nymphs and adults were greater than $39.2 \%$.

The surveys conducted by Baker et al. (2008), Vázquez et al. (2010) and Milla-Lewis et al. (2017), provided the accumulation of relevant information regarding the biological development of bed bugs of the genus Blissus, in forage poaceae, such as duration of the nymphal stage, life cycle length and survival rate. However, it is known that such biological aspects can vary according to the pest species, the host plant, and the local climatic conditions. So far there are no records in the literature on the biological aspects of the grasshopper bug $B$. pulchellus in Brazil, nor information on the main forage hosts and control methods.

In this sense, the objective of the present study is to evaluate the biological development of the grasshopper bug, $B$. pulchellus, regarding the resistance of eight forage plants.

\section{Materials and Methods}

The study was conducted at the Entomology Laboratory of Embrapa Roraima, during the period from May 2017 to October 2018, located at 2o 45’ 27.0” N and 60 43' 52.7” O.

\section{Bed bug breeding}

The initial population of blissid bugs in the laboratory was obtained from insects originating from infested clumps of Urochloa ruziziensis, brought from the field, and sent to the breeding room of the Entomology Laboratory of Embrapa Roraima and identified by Dr. Thomas Henry (USDA), where they were used for breeding and conservation of 50 specimens in $70 \%$ alcohol.

We individualized 36 couples of $B$. pulchellus, third generation (F3) according to (Valério et al, 2015), in acrylic Petri dishes ( $6.0 \mathrm{~cm}$ diameter $\times 2.0 \mathrm{~cm}$ high), lined with moist paper and parts of stem and sheathed leaves, cut three centimeters above the limb of $U$. ruziziensis, which were previously immersed in $1 \%$ sodium hypochlorite solution for $10 \mathrm{~min}$, followed by washing in distilled water. Every day the plant material was replaced by another, and the eggs originating from the spawning of the females were removed with the help of a brush, disinfected in $2 \%$ sodium hypochlorite solution for five minutes, washed in distilled water under a "voal" type sieve, counted and dated in spreadsheets and transferred to other Petri dishes until the hatching of the nymphs, to be used in the study (Brundage et al., 2016).

All Petri dishes were placed in a B.O.D. (Biochemical Oxygen Demand) chamber under controlled conditions of temperature $\left(27 \pm 5^{\circ} \mathrm{C}\right)$, relative humidity $(60 \pm 10 \%)$ and photophase of 12:12 hours (light:dark).

\section{Host plants}

The forage crops used - Urochloa ruziziensis (Ruziziensis), Urochloa humidicola (Humidicola), Andropogon gayanus 
(Andropogon), Panicum maximum cv. Mombaça (Mombaça), Panicum maximum cv. Zuri (Zuri), Urochloa brizantha cv. Marandú (Marandú), Urochloa brizantha cv. Piatã (Piatã), and Urochloa brizantha cv. Paiaguás (Paiaguás), were sown individually in plastic containers $(17.0 \times 8.0 \mathrm{~cm})$, prepared with a substrate based on soil, sand and bovine manure, in a proportion of 1:1:1 v/v. The forage plants were planted weekly, and 15 days after emergence (DAE) were used to obtain tender plant parts (leaves and stem) to feed the insects during the study. The containers with the plants were watered daily according to field capacity and fertilized with $10 \mathrm{~g}$ of N-P-K (10-12-10).

\section{Insect biology}

The trial was conducted in B.O.D., under conditions similar to those described for pest insect rearing. The treatments consisted of the eight forage species mentioned above, arranged in an entirely randomized design, with 100 repetitions, where each repetition was represented by an individual nymph in a Petri dish, fed with one of the forage species under test, according to the methodology used in breeding.

\section{Nymphal stage}

The nymphs were monitored daily until the emergence of adults, to record the viability (total initial nymph - total dead), number and duration of instars (number of times that there was a change of exoskeletons and the period between one phase and another), which was done through observation and collection of the exuvia (Valério et al., 2015).

\section{Adult phase}

After the emergence of the adults, they were sexed to form couples of the same age, which were individualized in Petri dishes, and remained together until the death of the female. It is worth noting that in the case of early death of the male, it was replaced by another of the same age.

Petri dishes with the $B$. pulchellus pairs and the forage under test were monitored daily to obtain the duration of the pre-reproductive, reproductive and post-reproductive periods of the females, as well as the longevity of adults and the biological cycle.

\section{Embryonic phase}

The eggs from the spawning females were collected and quantified to determine fecundity (number of eggs per female), duration of the embryonic period (incubation period), and egg viability (total number of hatched nymphs total number of eggs).

\section{Statistical analysis}

The data were submitted to normality (Shapiro-Wilk) and homogeneity (Hartley) variance tests, and when normal and homogeneous, were submitted to variance analysis with the application of the $\mathrm{F}$ test at $5 \%$ probability. Comparison of averages was performed by Tukey test at $5 \%$ probability using R software (R Development Core Team, 2018).

\section{Results and Discussion}

\section{Biological parameters of the nymphal stage}

Through the evaluation of the nymphal development of $B$. pulchellus it was possible to verify the occurrence of five instars and the duration period of each one (Table 1). The occurrence of five stages is in agreement with that observed in other species of the genus Blissus, such as $B$. leucopterus hirtus, $B$. arenarius arenarius, $B$. arenarius maritimus, $B$. insulares, $B$. barberi, B. breviusculus, B. sweeti, B. nanus, and B. minutus (Ohashi et al., 1980; Vásquez \& Sánchez, 1992; Baker et al., 2008). However, Kerr (1966), studying the biology of $B$. leucopterus, found six and seven nymphal instars, this being the only mention of the occurrence of more than five instars for Blissus species.

The first, second and fifth instars had the longest duration, especially the first, in all forage species/cultivars, while the fourth instar was the one with the shortest duration (Table 1). Similar results have been obtained in studies of the nymphal stage of B. leucopterus, although the duration time of each instar was shorter (Ohashi et al., 1980; Vásquez \& Sánchez, 1992).

The average time required for the nymphal development of B. pulchellus ranged from $36.9 \pm 0.34$ to $56.5 \pm 0.55$ days. The average length of each instar, as well as the nymphal period, were significantly longer in P. maximum cv. Zuri, U. humidicola, and $A$. gayanus when compared to the values observed in $U$.

Table 1. Duration (average \pm standard error) of nymphal developmental stages of the grasshopper bug (Blissus pulchellus) fed on eight forage species/cultivars.

\begin{tabular}{|c|c|c|c|c|c|c|}
\hline \multirow{2}{*}{ Species/Cultivars } & \multicolumn{5}{|c|}{ Instar (days) } & \multirow{2}{*}{$\begin{array}{l}\text { Nymphal } \\
\text { stage }\end{array}$} \\
\hline & $1^{\text {st }}$ & $2^{\text {nd }}$ & $3^{\text {rd }}$ & $4^{\text {th }}$ & $5^{\text {th }}$ & \\
\hline U. ruziziensis & $10.4 \pm 0.25 a$ & $10.5 \pm 0.25 a b$ & $6.6 \pm 0.23 \mathrm{a}$ & $5.4 \pm 0.11 \mathrm{a}$ & $7.6 \pm 0.16 a$ & $40.6 \pm 0.43 a$ \\
\hline U. brizantha cv. Piatã & $9.6 \pm 0.36 a$ & $9.3 \pm 0.24 \mathrm{a}$ & $6.2 \pm 0.11 \mathrm{a}$ & $4.8 \pm 0.11 \mathrm{a}$ & $7.0 \pm 0.15 a$ & $36.9 \pm 0.34 a$ \\
\hline U. brizantha cv. Paiaguás & $10.4 \pm 0.27 \mathrm{a}$ & $9.8 \pm 0.22 \mathrm{a}$ & $6.3 \pm 0.13 \mathrm{a}$ & $5.1 \pm 0.09 \mathrm{a}$ & $7.4 \pm 0.10 \mathrm{a}$ & $39.0 \pm 0.37 a$ \\
\hline U. brizantha cv. Marandú & $11.1 \pm 0.28 \mathrm{ab}$ & $10.8 \pm 0.35 a b$ & $6.9 \pm 0.14 a$ & $5.8 \pm 0.17 a$ & $7.3 \pm 0.10 a$ & $42.0 \pm 0.51 \mathrm{ab}$ \\
\hline P. maximum cv. Mombaça & $12.7 \pm 0.47 \mathrm{ab}$ & $11.2 \pm 0.32 a b$ & $7.9 \pm 0.13 a b$ & $5.9 \pm 0.15 a$ & $8.5 \pm 0.19 b$ & $46.2 \pm 0.57 \mathrm{ab}$ \\
\hline A. gayanus & $13.8 \pm 0.79 a b$ & $11.5 \pm 0.56 a b$ & $9.1 \pm 0.16 b$ & $8.1 \pm 0.20 b$ & $10.3 \pm 0.25 c$ & $52.8 \pm 0.77 b$ \\
\hline P. maximum cv. Zuri & $14.0 \pm 0.64 \mathrm{c}$ & $13.1 \pm 0.16 c$ & $10.0 \pm 0.22 b$ & $9.0 \pm 0.15 b$ & $10.4 \pm 0.21 c$ & $56.5 \pm 0.55 c$ \\
\hline U. humidicola & $15.6 \pm 0.57 c$ & $13.3 \pm 0.26 c$ & $9.2 \pm 0.16 b$ & $7.1 \pm 0.13 b$ & $10.7 \pm 0.22 c$ & $56.0 \pm 0.47 c$ \\
\hline CV\% & 9.18 & 9.80 & 7.92 & 7.04 & 12.07 & 18.03 \\
\hline
\end{tabular}

Averages followed by the same letter do not differ by Tukey test at $5 \%$ probability. 
brizantha cv. Piatã, U. brizantha cv. Paiaguás, and $U$. ruziziensis (Table 1). It is important to point out that the prolongation in the development of the nymphal stage observed, may indicate the presence of a strong effect of antibiosis and/or antixenosis factor(s) present in these forages, which need to be further elucidated.

Work with Bed Bugs of the genus Blissus has shown that feeding has a strong influence on nymphal development, which is in agreement with the findings of this article. Ohashi et al. (1980) found that the duration of the nymphal stage of $B$. leucopterus, was 70 days when fed on $U$. arrecta. The average values obtained in $U$. brizantha cvs. Paiaguás (39.0 \pm 0.37 days), Piatã (36.9 \pm 0.34 days), and $U$. ruziziensis (40.6 \pm 0.43 days), are close to those observed by Baker et al. (2008) and Vázquez et al. (2010), in studies with B. leucopterus fed on forage poaceous plants, who found duration between 35.5 and 37.0 days, respectively.

The percentage survival of $B$. pulchellus nymphs varied among forages throughout the evaluation period (Figure 1). Observing the graph, one can see a high mortality rate of the nymphs, mainly fed with $A$. gayanus and $P$. maximum cv. Zuri, indicating the existence of one or more resistance factors present in them.

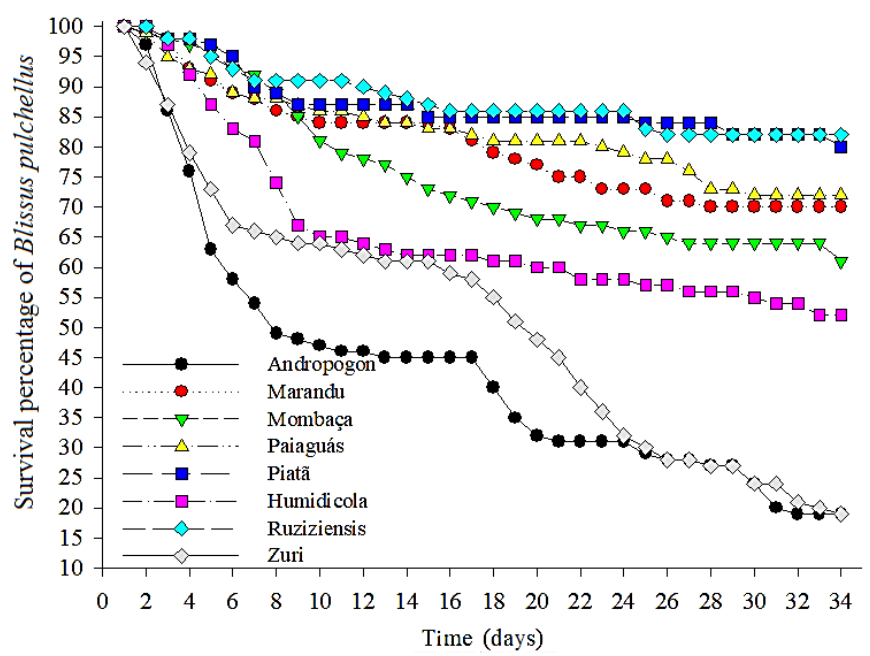

Figure 1. Percentage of survival of grass bug nymphs (Blissus pulchellus) fed on eight forage species for 34 days (time that referred to the lowest nymphal stage observed).
At the end of the nymphal stage, the lowest survival rates occurred in Zuri (17.0\%) and Andropogon (19.0\%), followed by Humidicola (56.0\%). While the highest were obtained in Piatã (78.0\%) and Ruziziensis (72.0\%) (Figure 2). According to Rangasamy et al. (2009) species that provide survival rates above $50 \%$ are considered susceptible to grass bugs, reinforcing the position of Zuri and Andropogon as resistant materials.

The high survival rates (above $70 \%$ ) observed in Ruziziensis and Piatã were similar to that obtained by Vázquez et al. (2010) in B. insularis fed on Stenotaphrum secundatum, with $76 \%$ survival of the nymphs.

The low percentage of insect survival in the immature stage, has been one of the most used parameters to classify a plant species as resistant, and this may be associated with the presence of antixenosis and/or antibiosis factors (Baldin et al., 2019).

Generally when survival is low, there is a strong indication of antibiosis occurring (Milla-Lewis et al., 2017). According to Rangasamy et al. (2009), the resistance of forage species to grasshopper bug attack is directly related to the presence of organic compounds in the tissues, such as cellulose, hemicellulose, and phenolic compounds. This could possibly explain the higher resistance in Zuri and Andropogon to $B$. pulchellus.

\section{Biological parameters of the adult phase}

The pre-reproductive period was longer in the forages $P$. maximum cv. Zuri and $A$. gayanus, with $7.3 \pm 0.66$ and $8.5 \pm$ 0.65 days, respectively, but did not differ from $U$. humidicola with $6.4 \pm 0.32$ days (Table 2). These values are in agreement with those observed by Vásquez and Sánchez (1992) of 7.6 days in B. leucopterus.

For insects, starting the reproductive phase in the first days of adulthood, and having a shorter pre-reproductive period, can be considered advantageous and desirable, because it increases the probability of perpetuation of the species. Thus, the fact that $A$. gayanus and $P$. maximum cv. Zuri, have promoted an extension of the pre-reproductive period, linked to a significant reduction of the reproductive period in the same forages ( $33.5 \pm 0.47$ and $32.3 \pm 2.16$ days, respectively), close to 10 days, compared to the forages, U. brizantha cvs.

Table 2. Duration (average \pm standard error) of the pre-reproductive, reproductive and post-reproductive periods, longevity, biological cycle and fecundity of female grasshopper bugs (Blissus pulchellus) fed on eight forage species/cultivars.

\begin{tabular}{|c|c|c|c|c|c|c|}
\hline \multirow{2}{*}{ Species/Cultivars } & \multicolumn{3}{|c|}{ Period (days) } & \multirow{2}{*}{$\begin{array}{l}\text { Longevity } \\
\text { of females }\end{array}$} & \multirow{2}{*}{$\begin{array}{c}\text { Biological } \\
\text { cycle* }\end{array}$} & \multirow{2}{*}{$\begin{array}{c}\text { Fecundity } \\
\text { (eggs/female) }\end{array}$} \\
\hline & Pre-reproductive & Reproductive & Post-reproductive & & & \\
\hline P. maximum cv. Zuri & $7.3 \pm 0.66 b$ & $32.3 \pm 0.21 \mathrm{a}$ & $1.5 \pm 0.24 \mathrm{ab}$ & $41.0 \pm 1.98 \mathrm{a}$ & $108.7 \pm 2.33 b c$ & $24.0 \pm 2.50 \mathrm{a}$ \\
\hline A. gayanus & $8.5 \pm 0.65 b$ & $33.5 \pm 0.47 a$ & $1.5 \pm 0.20 \mathrm{ab}$ & $43.5 \pm 0.87 a b$ & $106.6 \pm 1.02 b c$ & $26.4 \pm 4.23 \mathrm{a}$ \\
\hline U. humidicola & $6.4 \pm 0.32 a b$ & $35.2 \pm 0.80 \mathrm{~b}$ & $1.4 \pm 0.16 \mathrm{a}$ & $43.0 \pm 0.95 a b$ & $109.5 \pm 1.01 \mathrm{c}$ & $52.2 \pm 3.45 b$ \\
\hline P. maximum cv. Mombaça & $4.5 \pm 0.24 a$ & $39.3 \pm 0.91 b c$ & $2.9 \pm 0.24 b$ & $46.6 \pm 0.86 b c$ & $103.4 \pm 1.04 b c$ & $90.4 \pm 5.35 \mathrm{c}$ \\
\hline U. brizantha cv. Marandú & $3.4 \pm 0.39 \mathrm{a}$ & $44.3 \pm 0.59 c$ & $1.6 \pm 0.22 \mathrm{ab}$ & $49.4 \pm 0.87 c$ & $102.09 \pm 0.71 \mathrm{ab}$ & $100.9 \pm 3.77 c$ \\
\hline U. ruziziensis & $4.6 \pm 0.27 \mathrm{a}$ & $43.0 \pm 0.55 c$ & $2.1 \pm 0.29 a b$ & $49.7 \pm 0.57 c$ & $100.4 \pm 0.57 a$ & $110.3 \pm 3.11 d$ \\
\hline U. brizantha cv. Paiaguás & $4.4 \pm 0.34 \mathrm{a}$ & $44.1 \pm 0.59 \mathrm{c}$ & $1.8 \pm 0.22 \mathrm{ab}$ & $50.3 \pm 0.86 \mathrm{c}$ & $100.0 \pm 0.98 a$ & $123.9 \pm 3.19 \mathrm{~d}$ \\
\hline U. brizantha cv. Piatã & $4.9 \pm 0.30 \mathrm{a}$ & $43.8 \pm 0.36 c$ & $2.8 \pm 0.27 b$ & $51.4 \pm 0.58 c$ & $98.7 \pm 0.69 a$ & $142.1 \pm 3.92 d$ \\
\hline CV\% & 29.23 & 20.10 & 29.64 & 19.96 & 24.07 & 23.52 \\
\hline
\end{tabular}

*: Biological cycle = incubation period + nymphal stage + longevity of female. Averages followed by the same letter do not differ by Tukey's test at $5 \%$ probability. 
Marandú (44.3 \pm 0.59 days), Paiaguás (44.1 \pm 0.059 days), Piatã (43.8 \pm 0.36 days), and $U$. ruziziensis ( $43.0 \pm 0.55$ days), may indicate the presence of antibiosis factors.

The post-reproductive period $B$. pulchellus was short, ranging from $1.4 \pm 0.16$ to $2.9 \pm 0.24$ days, with an emphasis on $U$. humidicola, whose mean differed significantly from $P$. maximum cv. Mombasa and U. brizantha cv. Piatã (Table 2).

The longevity of females, obtained from the sum of the prereproductive, reproductive and post-reproductive periods, ranged from $41.0 \pm 1.98$ to $51.4 \pm 0.58$ days, with distinction for $P$. maximum cv. Zuri, $U$. humidicola, and $A$. gayanus, whose means were statistically different from the forages ( $F$ $=10.71, \mathrm{p}<0.0001)$ P. maximum cv. Mombaça, U. brizantha cvs. Marandú, Paiaguás, and Piatã, which presented the greatest longevity and supposedly offered the best nutritional conditions for the blissids. According to Wu et al. (2017), stress caused in forage plants by sucking insects causes an increase in the concentration of soluble nitrogen in the tissues, leading to increased growth and reproduction of the insects.

The duration of the biological cycle of $B$. pulchellus on forage crops ranged from $98.7 \pm 0.69$ to $109.5 \pm 1.01$ days, with shorter duration in $U$. brizantha cv. Piatã, $U$. brizantha cv. Paiaguás, and $U$. brizantha cv. Marandú and longer in $P$. maximum cv. Mombasa, A. gayanus, P. maximum cv. Zuri, and $U$. humidicola (Table 2). According to Grisoto et al. (2018), insects fed on resistant plants tend to have longer biological cycle length, which is increased mainly, by increasing the nymphal stage.

The fecundity of $B$. pulchellus females showed marked variation among forage species tested, with the lowest mean number of eggs per female in $P$. maximum cv. Zuri $(24.0 \pm 2.50)$ and $A$. gayanus $(26.4 \pm 4.30)$ eggs, followed by $U$. humidicola $(52.2 \pm 3.45)$, which were statistically different from the values recorded in the forage cultivars $U$. brizantha cv. Piatã (142.1 \pm $3.92)$ and Paiaguás $(123.9 \pm 3.19)$, and $U$. ruziziensis $(110.3 \pm$ 3.11) (Table 2).

The reduced fecundity observed by females of $B$. pulchellus fed on $P$. maximum cv. Zuri, and $A$. gayanus, compared to the other forages studied, reflects an intense presence of antibiosis factors, which may be associated with the existence in these plants of nutritional and/or allomonal improprieties of antibiotic action, which will act negatively on the physiology and biology of insects (Liu et al., 2017; Wu et al., 2017).

A plant expresses antibiosis-type resistance when insects when feeding normally on it experience adverse effects on its biology, and among other things, reduced fecundity, increased length of the developmental period, decreased adult longevity, and elevated mortality rate may occur (Baldin et a., 2019).

\section{Biological parameters of the embryonic phase}

The incubation period ranged from $10.3 \pm 0.27$ to $11.3 \pm$ 0.25 days, but there was no significant difference between the species (Table 3). Although the length of this period is one of the least important characteristics for resistance characterization, there is a tendency for eggs from insects reared on hosts with antibiosis-type resistance to have their
Table 3. Values (average \pm standard error) of incubation period length and viability of grasshopper (Blissus pulchellus) eggs fed on eight forage species/cultivars.

\begin{tabular}{ccc}
\hline Species/Cultivars & $\begin{array}{c}\text { Incubation } \\
\text { period (days) }\end{array}$ & $\begin{array}{c}\text { Egg } \\
\text { viability* }\end{array}$ \\
\hline P. maximum cv. Zuri & $11.3 \pm 0.25 \mathrm{a}$ & $17.8 \pm 1.56 \mathrm{a}$ \\
A. gayanus & $10.4 \pm 0.27 \mathrm{a}$ & $20.3 \pm 3.32 \mathrm{a}$ \\
U. humidicola & $10.6 \pm 0.26 \mathrm{a}$ & $39.7 \pm 3.25 \mathrm{a}$ \\
P. maximum cv. Mombaça & $10.7 \pm 0.24 \mathrm{a}$ & $76.8 \pm 4.59 \mathrm{~b}$ \\
U. brizantha cv. Marandú & $10.6 \pm 0.23 \mathrm{a}$ & $78.2 \pm 3.58 \mathrm{~b}$ \\
U. ruziziensis & $10.3 \pm 0.26 \mathrm{a}$ & $99.9 \pm 2.99 \mathrm{c}$ \\
U. brizantha cv. Paiaguás & $10.8 \pm 0.24 \mathrm{a}$ & $107.6 \pm 3.30 \mathrm{c}$ \\
U. brizantha cv. Piatã & $10.5 \pm 0.24 \mathrm{a}$ & $120.9 \pm 3.58 \mathrm{c}$ \\
CV\% & 10.12 & 24.61 \\
\hline
\end{tabular}

*: Hatched nymphs. Averages followed by the same letter do not differ by Tukey test at $5 \%$ probability.

incubation period increased and viability decreased (Grisoto et al., 2018).

As for egg viability, it was observed that $P$. maximum cv. Zuri, A. gayanus, and $U$. humidicola were the forages that least favored the hatching of nymphs, while $U$. brizantha cv. Paiaguás and $U$. brizantha cv. Piatã were responsible for the highest values, with $107.6 \pm 3.30$ and $120.8 \pm 3.58$ nymphs, respectively (Table 3 ). This viability response was directly proportional to the fecundity of the females (Table 2), since the greater number of eggs implied a greater number of nymphs.

Therefore, considering the results obtained in this study, the species $A$. gayanus and $P$. maximum cv. Zuri, at a higher degree and $U$. humidicola, at a moderate degree for some biological parameters, in relation to $B$. pulchellus, behaved as resistant when compared to the other forages, in this case, susceptible, P. maximum cv. Mombaça, U. brizantha cvs. Marandú, Paiaguás, Piatã, and $U$. ruziziensis.

Furthermore, based on the adverse effects observed on the biology of $B$. pulchellus, that is, low fecundity of females, reduced viability of eggs, high mortality, longer duration of the nymphal stage, shorter reproductive period and lower longevity of females, it was possible to state that this resistance is of the antibiosis type, and the possibility of antixenosis cannot be ruled out, since biophysical and/or biochemical antixenotic factors can make plants less suitable for feeding, negatively affecting the survival of the nymphs.

\section{Conclusions}

Andropogon gayanus, Panicum maximum cv. Zuri, and Urochloa humidicola, negatively affect the biology of Blissus pulchellus, causing prolongation of the nymphal period, high mortality of nymphs, reduced reproductive period, lower longevity of females, low fecundity, and low viability of eggs.

Andropogon gayanus, Panicum maximum cv. Zuri show high and Urochloa humidicola moderate antibiosis type resistance to Blissus pulchellus, and the possibility of antixenosis cannot be ruled out.

Urochloa ruziziensis, Urochloa brizantha cv. Paiaguás, and Urochloa brizantha cv. Piatã, show a high degree of susceptibility and $P$. maximum cv. Mombaça and $U$. brizantha 
cv. Marandú, a lower degree of susceptibility to Blissus pulchellus.

\section{Acknowledgments}

To the Programa de Pós-Graduação em Agronomia (POSAGRO-UFRR) and the Empresa Brasileira de Pesquisa Agropecuária (EMBRAPA-RORAIMA), for the research support.

\section{Compliance with Ethical Standards}

Author contributions: Conceptualization: JES; Data curation: ESS; Formal analysis: ESS; Funding acquisition: RDM; Investigation: ACSL; Methodology: ACSL; Project administration: ABB; Resources: EGF; Supervision: DAS; Validation: ROS; Visualization: JES; Writing - original draft: ESS, ACSL; Writing - review \& editing: ESS, JES, ACSL, DAS.

Conflict of interest: We declare that we have no financial, commercial, political, academic or personal conflict of interest with any company or individual, in conformity with the Conflict of Interest Policy of this publication. We also declare that the financial and (or) material support received for the development of this work are properly informed in the text, as well as the relationships of any kind that may lead to conflict of interest.

Financing source: Conselho Nacional de Desenvolvimento Científico e Tecnológico (CNPq).

\section{Literature Cited}

Baker, G.T.; Chen, X.; Ma, P.W.K. Labial tip sensilla of Blissus leucopterus leucopterus (Hemiptera: Blissidae): Ultrastructure and behavior. Insect Science, v.15, n.3, p.271-275, 2008. https:// doi.org/10.1111/j.1744-7917.2008.00210.x.

Baldin, E.L.L.; Vendramim, J.D.; Lourenção. Introdução. In: Baldin, E.L.L.; Vendramim, J.D.; Lourenção (Eds.). Resistência de plantas a insetos: fundamentos e aplicações. Piracicaba: FEALQ, 2019. Cap. 1, p.25-64.

Boiça Júnior, A.L.; Souza, B.H.S.; Ribeiro, Z.A.; Eduardo, W.I.; Nogueira, L.; Di Bello, M.M. Resistência de plantas: explorando o potencial de defesa aos insetos. In: Castilho, R.C. (Org.). Tópicos em Entomologia Agrícola - VIII. Jaboticabal: Gráfica Multipress Ltda, 2016. p.73-94.

Brundage, A.L; Crippen, T.L; Tomberlin, J.K. Methods for external disinfection of blow fly (Diptera: Calliphoridae) eggs prior to use in wound debridement therapy. Wound Repair Regen, v.24, n.2, p.1-10, 2016. https://doi.org/10.1111/wrr.12408.

Cao, H.-H.; Pan, M.-Z.; Liu, H.-R.; Wang, S.-H.; Liu, T.-X. Antibiosis and tolerance but not antixenosis to the grain aphid, Sitobion avenae (Hemiptera: Aphididae), are essential mechanisms of resistance in a wheat cultivar. Bulletin of Entomological Research, v.105, n 4, p.448-455, 2015. https://doi.org/10.1017/\$0007485315000322.

Grisoto, E.; Vendramim, J.D.; Lourenção, A.L.; Usberti Filho. J.A.; Olinda, R.A. Evaluation of forage grass resistance to. Mahanarva fimbriolata (Stål). Bragantia, v.77, n.1, p.107-115, 2018. https:// doi.org/10.1590/1678-4499.2016280.
Kerr, S. H. Biology of the lawn chinch bug, Blissus insularis. The Florida Entomologist, v.49, n.1, p.9-18, 1966. https://doi. org/10.2307/3493308.

Liu, J.; Zhu, J.; Zhang, P.; Han, L.; Reynolds, O.L.; Zeng, R.; Wu, J.; Shao, Y.; You, M.; Gurr, G.M. Silicon supplementation alters the composition of herbivore induced plat volatiles and enhances attraction of parasitoids to infested rice plants. Frontiers in Plant Science, v.8, n.19, p.1-8, 2017. https://doi.org/10.3389/ fpls.2017.01265.

Milla-Lewis, S.R.; Youngs, K.M.; Arrellano, C.; Cardoza, Y.J. Tolerance in St. Augustinegrass Germplasm against Blissus insularis Barber (Hemiptera: Blissidae). Crop Science, v.57, n.1, p. 26-36, 2017. https://doi.org/10.2135/cropsci2016.05.0361.

Moreira, M.A.B. Ocorrência do percevejo-das-gramíneas, Blissus leucopterus leucopterus (Say, 1832) (Hemiptera: Lygaeidae) na cultura do arroz em Roraima. Boa Vista: Embrapa; CPAF, 1996. 4p. (Embrapa/CPAF-Roraima. Comunicado Técnico, 1). https:// ainfo.cnptia.embrapa.br/digital/bitstream/item/175370/1/ cot00196-percevejo-marcos.pdf. 30 May. 2020.

Ohashi, O.S.; Reis, P.R.; Ciociola, A.I.; Rios, E. Bioecologia de Blissus leucopterus (Say, 1822) (Hemiptera-Lygaeidae) no estado de Minas Gerais. Belo Horizonte: EPAMIG, 1980. 26 p.

Pereira, R.P.; Silva, S.C. Ocorrência de Blissus leucopterus em pastagem do Estado do Rio de Janeiro. Pesquisa Agropecuária Brasileira, v. 23, n. 5, p. 551-553, 1988. https://seer.sct.embrapa. br/index.php/pab/article/view/13921/7902. 10 Jun. 2020.

R Development Core Team. R: A language and environment for statistical computing. Vienna: $R$ Foundation for Statistical Computing, 2018. https://www.r-project.org/. 07 Jun. 2020.

Ramm, C.; Wachholtz, M.; Amundsen, K.; Donze, T.; Heng-Moss, T.; Twigg, P.; Palmer, N.A.; Sarath, G.; Baxendale, F. Transcriptional profiling of resistant and susceptible buffalograsses in response to Blissus occiduus (Hemiptera: Blissidae) feeding. Journal of Economic Entomology, v.1, n.9, p.1354-1362, 2015. https://doi. org/10.1093/jee/tov067.

Rangasamy, M.; Mcauslane, H.J.; Backus, E.A.; Cherry, R.H. Differential probing behavior of Blissus insularis (Hemiptera: Blissidae) on resistant and susceptible St. Augustinegrasses. Journal of Economic Entomology, v.108, n.2, p.780-788, 2015. https://doi. org/10.1093/jee/tou061.

Rangasamy, M.; Rathinasabapathi, B.; Mcauslane, H. J.; Cherry, R. H.; Nagata, R.T. Role of leaf sheath lignification and anatomy in resistance against southern chinch bug (Hemiptera: Blissidae) in St. Augustinegrass. Journal of Economic Entomology, v.102, n.1 p.432-439, 2009. https://doi.org/10.1603/029.102.0156.

Silva, R.O. Fatores determinantes ao ataque do percevejo-dasgramíneas e de lagartas desfolhadoras em pastagens no município de Alto Alegre, Roraima. Boa Vista: Universidade Federal de Roraima, 2018. 70p. Dissertação Mestrado. http:// repositorio.ufrr.br:8080/jspui/handle/prefix/249. 30 May. 2020.

Simon, J.E. Morais, E.G.F.; Bendahan, A.B.; Schurt, D.A. Ocorrência de percevejos-das-gramíneas (Blissus sp.) em braquirão e Panicum maximum cv. Mombaça no Município de Alto Alegre Roraima. In: Semana Nacional de Ciência e Tecnologia do Estado de Roraima, 11., 2016, Boa Vista. Anais... Boa Vista: UERR, 2016. p.1-3. https://even3.azureedge.net/anais/36062.pdf. 03 Jun. 2020. 
Spike, B.P.; Wright, R. J.; Danielson, S.D. Chinch bug management (revised). Lincoln: University of Nebraska, 1993. 4p. (Neb Guide G86-806-A). https://digitalcommons.unl.edu/cgi/ viewcontent.cgi ?article $=2091 \&$ context=extensionhist. 01 Jun. 2020.

Sweet, M.H. Seed and chinch bug (Lygaeoidea), In: Schaefer, C.W.; Paninzzi, A.R. (Eds.), Heteroptera of economic importance. Boca Raton: CRC Press LLC, 2000. p. 143-264.

Valério, J.R.; Reis, P.R.; Lima, O.G. Percevejo-das-gramíneas, Blissus leucopterus. In: Vilela, E.F.; Zucchi, R.A. (Orgs.). Pragas introduzidas no Brasil: insetos e ácaro. Piracicaba: FEALQ, 2015. p.708-719.
Vásquez, J.M.N; Sánchez, G.G. Biología, hábitos y huéspedes de la chinche de las raíces Blissus leucopterus (Say) (Hemiptera: Lygaeidae). Revista Colombiana de Entomología, v.17, n.l, p.8-15, 1992. https:// www.cabi.org/isc/abstract/19941109287. 02 May. 2020.

Vázquez, J.C.; Hoy, M.A.; Royalty, R.N.; Buss, E.A. A synchronous rearing method for Blissus insularis (Hemiptera: Blissidae). Journal of Economic Entomology, v.103, n.3, p.726-734, 2010. https://doi.org/10.1603/EC09254.

Wu, X.; Yu, Y.; Baerson, S.R.; Song, Y.; Liang, G.; Ding, C.; Niu, J.; Pan, Z.; Zeng, R. Interactions between nitrogen and silicone in rice and their effects on resistance toward the brown planthopper Nilaparvata lugens. Frontiers in Plant Science, v.8, n.28. p.1-11 2017. https://doi.org/10.3389/fpls.2017.00028. 